\title{
MANAJEMEN PENDIDIKAN AGAMA ISLAM \\ DI PERGURUAN TINGGI UMUM \\ (Studi Kasus di Institut Pertanian Bogor)
}

\section{Furqon Syarief Hidayatulloh}

Institut Pertanian Bogor (IPB)

Jl. Riau Babakan Asem No 6 Baranangsiang-Bogor

Email: furqonsyarief@gmail.com

\begin{abstract}
ABSTRAK
Penelitian ini bertujuan menggambarkan pelaksanaan pengelolaan/manajemen Pendidikan Agama Islam (PAI) di Perguruan Tinggi Umum (PTU-Non Keagamaan). Lokasi yang dipilih adalah Institut Pertanian Bogor (IPB). Penelitian ini menggunakan teknik studi kasus, karena itu termasuk penelitian kualitatif. Data diperoleh dengan cara melakukan wawancara mendalam, analisis dokumentasi dan pengamatan partisipatif. Hasil penelitian menunjukkan bahwa pelaksanaan manajemen PAI di IPB secara umum meliputi: 1) Program pengadaan dosen baru (penentuan kebutuhan, rekrutmen dan seleksi, dan pengangkatan dan penugasan), 2) Manajemen pembagian jadwal mengajar (Kordinator mengundang dosen, dosen diminta memilih hari, jam dan kelas sesuai dengan kesiapan, dan memilih dosen pendamping), 3) Manajemen pembelajaran PAI (Kuliah, Asistensi, dan Studium General), dan 4) Program tindak lanjut.
\end{abstract}

Kata Kunci: Manajemen, Pendidikan Agama Islam, Perguruan Tinggi Umum.

\section{ABSTRACT}

This study aims at describing the implementation of management/management of Islamic Education (PAI) in Public Higher Education (PTU-Non-Religious). The research site chosen is the Bogor Institute of Agriculture (IPB). This study is a case study because it includes qualitative research. The data were collected through in-depth interviews, analysis and documentation of participatory observation. The results showed that the implementation of the PAI in IPB management generally includes: 1) procurement program of new teaching staff (determination of requirements, recruitment and selection, and appointment and assignment), 2) Management division of teaching schedule (Coordinator invites lecturers, lecturers are asked to select the days, hours and class in accordance with readiness, and selecting l teaching assisstant), 3) PAI Learning Management (Lecture, Assistance, and Studium General), and 4) followup program.

Keywords: Management, Islamic Education, Public Higher Education. 


\section{PENDAHULUAN}

Tujuan pendidikan nasional sebagaimana dinyatakan dalam UndangUndang Republik Indonesia Nomor 20 Tahun 2003 tentang Sistem Pendidikan Nasional, pasal 3 yaitu bertujuan untuk mengembangkan potensi peserta didik agar menjadi manusia yang beriman dan bertakwa kepada Tuhan Yang Maha Esa, berakhlak mulia, sehat, berilmu, cakap, kreatif, mandiri dan menjadi warga negara yang demokratis serta bertanggung jawab. Rumusan tersebut menegaskan pula bahwa tujuan penyelenggaraan pendidikan di perguruan tinggi pun pada dasarnya menciptakan sumber daya manusia Indonesia yang berkualitas dan sempurna (insân kâmil), yakni manusia yang beriman, bertakwa, berakhlakul karimah, sehat, berilmu, kreatif, cakap, berbudaya dan menjadi warga negara yang demokratis serta bertanggungjawab.

Mewujudkan atau membentuk manusia Indonesia yang tercermin dalam undang-undang tersebut utamanya diupayakan melalui pendidikan agama, baik pendidikan yang diselenggarakan secara formal, informal maupun non formal. Penyelenggaraan pendidikan agama secara formal dapat berupa pemberian suatu bidang studi yang bertujuan menanamkan nilai-nilai agama. Prosesnya dapat melalui pembelajaran dan dikemas dalam bentuk mata pelajaran atau mata kuliah, yang diberi nama Pendidikan Agama (Islam atau non Islam) (Syahidin, 2004: 4 dan 2006).

Dalam struktur kurikulum nasional pendidikan tinggi, Mata Kuliah Pendidikan Agama Islam merupakan mata kuliah yang wajib diikuti oleh semua mahasiswa yang beragama Islam di seluruh perguruan tinggi umum, pada setiap jurusan, program dan jenjang pendidikan, baik di perguruan tinggi negeri maupun swasta (Syahidin, 2004: 5 dan 2006). Dengan diwajibkannya semua perguruan tinggi agar memuat atau memberikan kurikulum tersebut, hal ini mencerminkan bahwa; 1) ada itikad baik dan serius dari pemerintah dalam upaya mewujudkan peserta didik, dalam hal ini mahasiswa (sebagai generasi pelanjut pembangunan bangsa), yang berkualitas sebagaimana tercermin dalam tujuan pendidikan nasional di atas; 2) secara normatif-fungsional, penyelenggaraan Pendidikan Agama (Islam khususnya), dipandang dan diyakini secara langsung dapat memberikan kontribusi terhadap pengembangan kepribadian mahasiswa.

Visi Pendidikan Agama Islam (PAI) di perguruan tinggi umum yaitu, "menjadikan ajaran Islam sebagai sumber nilai dan pedoman yang mengantarkan mahasiswa dalam mengembangkan profesi dan kepribadiannya secara Islami" (Depdiknas, Direktorat Pembinaan Pendidikan Tenaga Kependidikan dan Ketenagaan Perguruan Tinggi, 2004: 2). Misi Pendidikan Agama Islam di perguruan tinggi umum (PTU) ialah "mengembangkan pribadi mahasiswa agar menjadi sarjana yang beriman, bertakwa, dan berakhlak mulia menurut ajaran Islam" (Furqon, 2004). Mengingat pentingnya misi tersebut maka PAI perlu mendapatkan perhatian secara serius. PAI harus dikelola secara profesional, teratur, baik dan terencana. PAI di Perguruan Tinggi Umum harus dijaga, dikembangkan dan dikelola keberadaannya dengan sebaik-baiknya. 
Bagaimanapun juga, sesuatu yang dikerjakan dengan cara-cara yang baik, teratur dan terencana dapat memberikan peluang yang lebih besar untuk tercapainya tujuan yang dikehendaki. Berarti PAI perlu dikelola dengan baik.

Berhubungan dengan ilmu manajemen, Siswanto (2005: 103) mengungkapkan bahwa manajemen memiliki peran yang sangat menentukan dalam usaha mencapai tujuan organisasi yang telah ditetapkan. Peran manajemen adalah menjaga agar usaha pencapaian tujuan tersebut dapat berlangsung secara berdaya guna (effective) dan berhasil guna (efficient). Tercapainya tujuan organisasi, baik jangka pendek, menengah maupun jangka panjang sangat dipengaruhi oleh manajemen. Tanpa manajemen yang baik usaha untuk mencapai tujuan organisai akan sulit dilakukan. Hasibuan (2006: 3-4) menegaskan bahwa manajemen itu penting dan diperlukan dalam kegiatan apa pun, sebab; 1) suatu pekerjaan itu pada dasarnya berat dan sulit untuk dikerjakan sendiri, sehingga diperlukan pembagian kerja, tugas dan tanggung jawab dalam menyelesaikannya; 2) manajemen yang baik akan memaksimalkan semua potensi yang dimiliki organisasi; 3) manajemen yang baik akan mengurangi pelbagai pemborosan; 4) manajemen memberi dampak pada pencapaian tujuan secara teratur.

Dalam konteks Pendidikan Agama Islam (PAI) di Perguruan Tinggi Umum (PTU), manajemen atau pengelolaan sangat diperlukan dalam rangka memudahkan pencapaian tujuan Pendidikan Agama Islam yang dikehendaki, mengoptimalkan sumber daya yang ada serta untuk meminimalisir pelbagai pemberosan seperti tenaga, keuangan, sarana prasarana dan waktu. Penelitian ini bertujuan untuk mengetahui pelaksanaan pengelolaan/manajemen Pendidikan Agama Islam yang di diterapkan di IPB. Penelitian ini menggunakan teknik studi kasus, karena itu termasuk penelitian kualitatif. Data diperoleh dari wawancara mendalam, analisis dokumentasi dan pengamatan partisipatif. Ruang lingkup penelitian ini difokuskan pada manajemen pengadaan tenaga pendidik, manajemen pembagian jadwal mengajar, manajemen pembelajaran (pemilihan materi, metode serta penggunaan media pengajaran), pengembangan program dan tindak lanjut.

\section{PEMBAHASAN}

Secara etimonologis, kata manajemen berasal dari bahasa Inggris, management, yang berarti ketatalaksanaan, tata pimpinan dan pengelolaan (Echols dan Shadily, 1996). Artinya, manajemen adalah sebagai suatu proses yang diterapkan oleh individu maupun kelompok dalam menata, memimpin dan mengelola sesuatu untuk mencapai suatu tujuan. Dalam bahasa Arab, istilah manajemen diartikan sebagai an-nizhâm berarti susunan, tatanan, sistem, teratur (Munawwir, 1984). An-nizhâm berasal dari kata nazhama. Ną̧hamal asyaa' nazhman berarti menata beberapa hal dan menggabungkan antara satu dengan yang lainnya. Nazhama amrahu berarti menyusun dan menertibkan sesuatu. An-nizhâm berarti tertib dan teratur (al Wajiz, 2004: 118-119). Dari pengertian ini dapat dipahami bahwa manajemen (bahasa arab, an-niz̧âm; at-tanz̧him) adalah aktivitas 
menyusun, menertibkan dan mengatur yang dilakukan oleh seseorang atau kelompok, sehingga mampu mengurutkan, menata dan merapikan hal-hal yang diperlukan dalam mencapai suatu tujuan.

Secara terminologis, Stoner seperti yang dikutip oleh Sagala (2007: 51) mengungkapkan bahwa manajemen adalah proses dari perencanaan, pengorganisasian, pelaksanaan dan pengendalian dari pimpinan terhadap usaha para anggota organisasi dalam memanfaatkan sumber-sumber daya yang ada untuk mencapai tujuan organisasi yang telah ditetapkan. Hasibuan (2006: 2) mengungkapkan bahwa manajemen adalah seni mengatur proses pemanfaatan sumber daya manusia dan sumber-sumber lainnya secara efektif dan efisien untuk mencapai suatu tujuan tertentu. Siagan (2005: 1) menjelaskan bahwa manajemen adalah seni memperoleh hasil melalui berbagai kegiatan yang dilakukan oleh orang lain. Hersey dan Blanchar yang dikutip oleh Syafaruddin (2005: 4) menegaskan bahwa manajemen adalah proses bekerja sama antar individu dan kelompok serta sumber daya lainnya dalam mencapai tujuan organisasi.

Dari pelbagai definisi di atas, diperoleh pemahaman bahwa: 1) manajemen mempunyai tujuan yang ingin dicapai; 2) manajemen baru dapat diterapkan bila terdapat dua orang atau lebih yang melakukan kerja sama dalam suatu organisasi; 3) manajemen hanya merupakan alat untuk mencapai tujuan dengan pemanfaatan sumber daya manusia dan sumber daya lainnya secara efektif dan efisien dalam suatu organisasi; 4) manajemen memiliki fungsi perencanaan, pengorganisasian, penggerakan, pengendalian dan pengawasan.

Pendidikan Agama Islam itu sendiri, menurut Direktorat Pembinaan Pendidikan Agama Islam pada Sekolah Umum Negeri (Ditbinpaisun) sebagaimana yang dikutip oleh Daradjat (1992: 88) adalah suatu usaha bimbingan dan pengasuhan terhadap peserta didik agar kelak setelah selesai dari pendidikan dapat memahami hal-hal yang terkandung di dalam ajaran Islam secara keseluruhan, menghayati makna, maksud dan tujuannya serta dapat mengamalkan atau menjadikan ajaran Islam yang telah dianutnya sebagai pandangan hidup sehingga dapat menyelamatkan dirinya baik di dunia maupun di akhirat. Berarti, penyelenggaraan Pendidikan Agama Islam di Perguruan Tinggi Umum pun pada dasarnya bermaksud memberikan landasan nilai-nilai ajaran Islam kepada para mahasiswa dalam mengembangkan ilmu pengetahuan yang ditekuninya. Dengan demikian, penyelenggaraan Mata Kuliah Pendidikan Agama Islam merupakan sarana untuk mewujudkan mahasiswa menjadi sarjana Muslim yang memiliki keimanan dan ketakwaan kepada Allah SWT, kepribadian yang mulia serta menguasai ilmu pengetahuan dan teknologi dengan baik.

Adapun fungsi Pendidikan Agama di sekolah (termasuk perguruan tinggi) yaitu; (1) Pengembangan, yakni meningkatkan keimanan dan ketakwaan peserta didik kepada Allah SWT yang telah ditanamkan dalam lingkungan keluarga. Upaya ini dapat dilakukan melalui bimbingan, pengajaran dan pelatihan; (2) Penyaluran, yakni menyalurkan peserta didik yang memiliki bakat khusus di 
bidang agama agar bakat tersebut dapat berkembang secara optimal; (3) Perbaikan, yaitu untuk memperbaiki kesalahan-kesalahan, kekurangankekurangan dan kelemahan-kelemahan peserta didik dalam hal keyakinan, pemahaman dan pengamalan ajaran Islam dalam kehidupan sehari-hari; (4) Pencegahan, yaitu menangkal hal-hal negatif dari lingkungan atau dari budaya lain yang dapat membahayakan dirinya dan menghambat perkembangannya menuju manusia Indonesia seutuhnya; (5) Penyesuaian, yaitu untuk menyesuaikan diri dengan lingkungannya, baik lingkungan fisik maupun lingkungan sosial dan dapat mengubah lingkungannya sesuai dengan ajaran Islam (Ramayulis, 2005: 21-22).

Asnelly Ilyas mengungkapkan bahwa "Pendidikan Islam berfungsi sebagai sarana atau alat untuk menyelamatkan manusia dari siksaan api neraka (Ilyas, 1995: 13). Dengan demikian, dalam konteks Perguruan Tinggi Umum, maka fungsi Pendidikan Agama Islam adalah (1) upaya untuk meningkatkan keimanan dan ketaqwaan mahasiswa kepada Allah SWT melalui bimbingan, pengajaran dan pelatihan, (2) menyalurkan mahasiswa yang memiliki bakat khusus di bidang agama seperti tilawah al-Qur'an, Khat al-Qur'an dan Hifdzil Qur'an, (3) memperbaiki kesalahan-kesalahan serta kekurangan-kekurangan mahasiswa dalam keyakinan, pemahaman dan pengamalan ajaran Islam dalam kehidupan sehari-hari, (4) membentengi mahasiswa dari perbuatan-perbuatan atau budaya-budaya yang dapat membahayakan dirinya, bahkan pemikiran-pemikiran yang sesat dan menyesatkan, (5) memberikan pembekalan kepada mahasiswa agar memiliki kemampuan untuk mengubah lingkungannya sesuai dengan ajaran Islam, (6) sebagai sarana dalam menyelamatkan mahasiswa dari siksaan api neraka, karena dalam pendidikan agama Islam diajarkan tentang hal-hal yang bisa menyelamatkan manusia dari api neraka.

Menurut Nasir (2002: 23) landasan/dasar pelaksanaan Pendidikan Agama Islam di Indonesia, khususnya di Perguruan Tinggi Umum dapat ditinjau dari aspek religius, psikologis dan yuridis formal.

Pertama, aspek religius. Di dalam al-Qur'an dan hadis Nabi Muhammad SAW banyak dinukilkan bahwa manusia ketika masih di alam ruh dahulu sebenarnya telah berjanji untuk percaya kepada Allah SWT, misalnya dalam al Quran surat Al-'Arâf [7]: 172:

"Dan (ingatlab), ketika Tuhanmu mengeluarkan keturunan anak-anak. Adam dari sulbi mereka dan Allah mengambil kesaksian terhadap jiwa mereka (seraya berfirman): "Bukankah aku ini Tubanmu?" mereka menjawab: "Betul (Engkau Tuban kami), Kami menjadi saksi". (Kami lakukan yang demikian itu) agar di hari kiamat kamu tidak mengatakan: "Sesungguhnya Kami (Bani Adam) adalah orang-orang yang lengah terbadap ini (keesaan Tuhan)" (Digital Qur'an versi 3.2 juz 8).

Setiap manusia memiliki fitrah atau naluri untuk beragama yang lurus (agama tauhid), yaitu agama Islam. Allah SWT berfirman dalam surat Ar-Rum [30]: 30: 
"Maka hadapkanlah wajahmu dengan Lurus kepada agama Allab; (tetaplah atas) fitrah Allah yang telah menciptakan manusia menurut fitrah itu. tidak ada peubahan pada fitrah Allah. (Itulah) agama yang lurus; tetapi kebanyakan manusia tidak. mengetabui" (Digital Qur'an versi 3.2 juг 21).

Dalam hadits Nabi SAW dijelaskan bahwa setiap manusia yang dilahirkan adalah fitrah, Rasulullah SAW bersabda, "Setiap anak (manusia) itu dilahirkan dalam keadaan suci hingga dia dapat berbicara. Maka orang tuanyalah yang menjadikannya menjadi seorang Yahudi, Nasrani atau Majusi" (HR. Aswad bin Sari'). Menurut Mujib (1999: 16) hadis tersebut berhubungan dengan masalah potensi yang bersifat universal dari setiap anak yang dilahirkan. Makna fitrah dalam hadis di atas menurut dia mengisyaratkan adanya takdir manusia atau status anak yang dilahirkan selalu dalam kondisi psikis yang berpotensi untuk menjadi muslim.

Kedua, aspek psikologis: Pada diri manusia itu terdapat kebutuhan pokok. Beliau mengemukakan, bahwa manusia di samping mempunyai kebutuhan jasmani dan rohani juga mempunyai kebutuhan akan kehidupan jiwanya agar agar keduanya seimbang dan salah satunya tidak mengalami tekanan. Adapun unsur-unsur kebutuhan tersebut adalah 1) kebutuhan akan rasa kasih sayang; kebutuhan yang menyebabkan manusia selalu mendambakan rasa kasih sayang; 2) kebutuhan akan rasa aman yakni kebutuhan yang mendorong manusia mengharapkan adanya perlindungan; 3) kebutuhan akan rasa harga diri yaitu kebutuhan yang mendorong manusia agar dirinya dihormati dan diakui oleh orang lain; 4) kebutuhan akan rasa bebas yakni kebutuhan yang menyebabkan seseorang bertindak secara bebas, untuk mencapai kondisi dan situasi rasa lega; 6) kebutuhan akan kesuksesan yaitu kebutuhan manusia yang menyebabkan ia mendambakan rasa ingin untuk dibina dalam bentuk penghargaan terhadap hasil karyanya; 7) kebutuhan akan rasa ingin tahu (mengenal), ialah kebutuhan yang menyebabkan manusia selalu meneliti dan menyelidiki sesuatu (Daradjat dalam Jalaludin, 1997: 60).

Ketiga, aspek yuridis formal. Maksudnya, perundang-undangan dan segenap peraturan yang berlaku, baik secara langsung maupun tidak langsung dapat dijadikan dasar pelaksanaan Pendidikan Agama Islam. Secara yuridis, ada tiga dasar pelaksanaan Pendidikan Agama yaitu: 1) dasar ideal, 2) dasar konstitusional, 3) dasar operasional (Nasir, 2002: 45). Dasar ideal yang dimaksud adalah Pancasila. Dengan pancasila, terutama sila pertama maka seluruh bangsa Indonesia harus percaya kepada Tuhan Yang Maha Esa. Kepercayaan tersebut harus melalui jalur beragama. Dasar konstitusional penyelenggaraan PAI di PTU terdapat dalam UUD 1945, Bab XI, Pasal 29, ayat 1 dan 2 disebutkan: (1) Negara berdasarkan atas Ketuhanan Yang Maha Esa. (2) Negara menjamin kemerdekaan tiap-tiap penduduk untuk memeluk agamanya masing-masing dan untuk beribadah menurut agamanya dan kepercayannya itu. Dasar operasional, maksudnya, dasar yang secara langsung mengatur pelaksanaan Pendidikan Agama (Islam) itu sendiri (Nasir, 2002: 46). Di dalam Undang-Undang Sistem 
Pendidikan Nasional No. 20 Tahun 2003, Bab X, pasal 37, poin 2 dinyatakan bahwa: "Kurikulum Pendidikan Tinggi wajib memuat: (1) Pendidikan Agama, (2) Pendidikan Kewarganegaraan, dan (3) bahasa". Dalam Peraturan Pemerintah RI No 19 Tahun 2005, Bab III, Pasal 29, ayat 2, tentang Standar Nasional Pendidikan dinyatakan bahwa: "Kurikulum tingkat satuan Pendidikan Tinggi wajib memuat Mata Kuliah Pendidikan Agama, Pendidikan Kewarganegaraan, Bahasa Indonesia, dan Bahasa Inggris." Implikasinya, bahwa dalam penyusunan kurikulum Pendidikan Tinggi wajib memuat mata kuliah Pendidikan Agama, termasuk PAI.

Sebagai sebuah pengorganisasian, usaha untuk pencapaian tujuan Pendidikan Agama Islam harus digerakan oleh sesuatu yang dinamis, yang disebut dengan manajemen (Siswanto, 2005: 101). Dalam konteks penyelenggaraan Pendidikan Agama Islam, manajemen berperan dalam menentukan dan mewujudkan usaha tercapainya tujuan pendidikan Agama Islam. Dengan menerapkan prinsip-prinsip manajemen dan mengoptimalkan sumber daya yang dimiliki, maka tujuan tersebut besar kemungkinan dapat tercapai dengan baik. Ruang lingkup manajemen PAI di perguruan tinggi umum meliputi bidang; 1) manajemen pengadaan tenaga pendidik. Bidang ini berisi proses dan prosedur tertentu dalam hal pengadaan tenaga dosen/asisten dosen Agama Islam yang mencakup kegiatan penentuan kebutuhan, rekrutmen dan seleksi, pengangkatan dan penugasan; 2) manajemen pembagian jadwal mengajar. Pembagian jadwal mengajar pada Mata Kuliah Pendidikan Agama Islam di perguruan tinggi umum pada prinsipnya harus didasarkan kepada beban kerja ideal dosen. Dalam satu semester beban kerja ideal dosen adalah 40 jam/minggu yang meliputi bidang pendidikan dan pengajaran, penelitian dan pengabdian masyarakat. Dalam bidang pengajaran, idealnya dosen mengajar sekitar 18 jam per minggu (Departemen Pendidikan Nasional Biro Kepegawaian, 2005: 3); dan 3) manajemen pembelajaran. Inti dari pendidikan adalah adanya proses pembelajaran, yaitu terjadinya interaksi/saling respons di antara pendidik sebagai pengajar dan peserta didik/murid/siswa. Pola interaksi antara pendidik dengan peserta didik ini perlu ditata, dikelola atau dengan kata lain dimenej dengan sebaik-baiknya agar tujuan pendidikan yang dikehendaki dapat tercapai dengan baik. Untuk itu, pendidik harus mengetahui, mengenal dan memahami sejumlah komponen yang terdapat dalam proses pembelajaran. Sebagai suatu sistem, pembelajaran terdiri atas beberapa komponen yang satu sama lain saling berinteraksi. Komponen-komponen itu antara lain adalah tujuan, materi, metode atau strategi pembelajaran, media dan evaluasi pembelajaran (Sanjaya, 2008: 58). Komponen yang paling penting dalam pembelajaran adalah pendidik dan peserta didik itu sendiri.

Manajemen Pendidikan Agama Islam adalah suatu proses pengaturan dan penataan serta pengelolaaan terhadap sumber daya manusia dan sumber-sumber lainnya secara optimal (efektif dan efisien) dalam upaya membimbing dan mengasuh peserta didik agar nantinya setelah selesai pendidikan mereka dapat 
memahami, menghayati dan mengamalkan ajaran Islam sehingga pada akhirnya mereka mendapatkan kebahagiaan hidup di dunia dan di akhirat. Manajemen Pendidikan Agama Islam mengandung beberapa unsur, yaitu; 1) adanya aktivitas atau kegiatan yang dilakukan secara efektif dan efisien; 2) adanya hasil tujuan yang hendak dicapai; 3) adanya orang yang melakukan serangkaian kegiatan yang telah ditentukan; 4) adanya sarana atau media yang dapat menunjang terhadap pencapaian tujuan yang dikehendaki.

\section{Manajemen PAI di IPB}

Penyelenggaraan Pendidikan Agama Islam (PAI) di Institut Pertanian Bogor (IPB) dilaksanakan tidak lama setelah IPB lahir yaitu sekitar tahun 1963. Pemberian materi Agama Islam di IPB ini secara historis dilatarbelakangi oleh adanya kekhawatiran sebagian akademisi (Muslim) terhadap masuknya paham Nasakom (Nasionalisme Agama dan Komunis) ke dalam kampus yang pada saat itu telah menyebar ke seluruh tanah air Indonesia. Sebagai akibat dari adanya kekhawatiran tersebut maka dibentuk suatu tim yang memiliki perhatian terhadap keselamatan sivitas akademika terutama dari masalah agama, yaitu Tim Pendidikan Agama Islam IPB yang beranggotakan tiga orang yakni Edman, Amin Aziz dan Aziz Darwis (Hasil wawancara dengan Abdul Azizi pada Hari Jum'at tanggal 11 April 2008). Ketiga orang tersebut memiliki keinginan untuk merekrut terus tenaga pengajar (dosen) Pendidikan Agama Islam yang diambil baik dari dalam maupun dari luar IPB. Keinginan tim ini akhirnya membuahkan hasil yakni dengan diangkatnya Bapak Supan dari lingkungan IPB dan Bapak Dimyati serta Abdul Qadir Zailani dari luar IPB menjadi dosen PAI di kampus tersebut.

Sehubungan dengan status dosen Pendidikan Agama Islam yang telah direkrut itu bukan dosen tetap, maka sekitar tahun 1970 tim Pendidikan Agama Islam (TPAI) memiliki keinginan kembali untuk merekrut/ mengangkat dosen tetap Pendidikan Agama Islam di IPB. Keinginan tersebut yang diusulkan kepada rektor, yang pada waktu itu dijabat oleh Dr Andi Hakim Nasution. Rektor menginginkan bahwa dosen tetap yang diusulkan tersebut memiliki latar belakang ilmu keagamaan yang baik, misalnya lulusan dari Institut Agama Islam Negeri (IAIN) (Tim Pendidik Agama Islam, 2007).

Sekitar tahun 1977 harapan tim terealisasi. Hal ini ditandai dengan diangkatnya Komariah sebagai dosen tetap Pendidikan Agama Islam pertama di IPB, disusul oleh Ida, namun beliau tidak lama karena harus mengikuti suaminya ke Kalimantan. Kemudian Ruminah (beliau diangkat oleh Depag dan selanjutnya diperbantukan di IPB). Pada saat itu, kordinator Tim PAI adalah Supan ( Hasil wawancara dengan Komariah, pada hari Kamis tanggal 10 April 2008).

Wawancara dengan kordinator PAI IPB yaitu E. Syamsuddin pada hari Sabtu tangagal 19 April 2008 mengegaskan bahwa tahun 1980-1981-an, IPB mengangkat kembali dua orang dosen tetap untuk mata kuliah Pendidikan Agama Islam. Mereka adalah Didin Hafidhuddin, dan Ahmad Djuwaeni. 
Dengan demikian, pada tahun 1980-an dosen tetap PAI di IPB berjumlah empat orang. Jika ditambah dengan dosen tidak tetap maka semuanya menjadi tujuh orang yaitu Supan, Abdul Qadir Zailani, Aam Saefudin, Lukman, Mujahid dan Sumanjaya. Pada saat itu, Didin Hafidhuddin diangkat menjadi koordinatornya. Pada tahun 1985 IPB mengangkat dosen tetap PAI satu orang lagi yaitu E. Syamsuddin dan pada tahun 2000 mengangkat satu orang lagi yaitu Romli Suja'i. Selanjutnya, pada tahun 2005, IPB mengangkat kembali dua orang, yaitu Asep Nurhalim dan Furqon Syarief Hidayatulloh. Tahun 2006 IPB mengangkat lagi satu orang, yaitu ibu Neneng Hasanah (beliau dosen yang diangkat oleh Depag/Kemenag. yang diperbantukan untuk IPB). Sejak tahun 1986 sampai sekarang, E syamsuddin menjadi koordinatornya. Dengan demikian, jumlah dosen tetap Pendidikan Agama Islam di IPB sampai saat ini (2013) ada sembilan orang. Delapan orang mengajar di program S1 dan satu orang ditugaskan mengajar di program Diploma yaitu Dra. Komariah. Kini koordinator Tim PAI IPB dijabat oleh Dra. Komariah. Dosen luar biasa Pendidikan Agama Islam di IPB saat ini berjumlah 12 orang, diantaranya Dr. Hamim, Dr. Irzaman, Dr. Hasyim, Dr. Ahmad, Dr, Munif, Drs. Hamzah, Drs. Faried, Musthofa S.Ag. Ahmad Shaleh S.Ag, Wasto S.Hut, Hajarul Aswad S.Pd dan Ir. Mat Yamin MT.

Nama-nama dosen tetap/PNS PAI hingga tahun 2008, berdasarkan kualifikasi pendidikannya adalah 1) Dra. Totom Komariyah (S-1 lulusan IAIN Yogyakarta Jurusan Dakwah); 2) Prof Dr Didin Hafidhuddin (S-1 lulusan IAIN Jakarta Jurusan Syari'ah, S-2 lulusan IPB Jurusan Penyuluhan Pembangunan dan S-3 lulusan IAIN Jakarta Jurusan Pengkajian Islam); 3) Dra. Ruminah (S-1 lulusan IAIN Jakarta Jurusan Dakwah); 4) Drs Djuwaeni MA (S-1 lulusan IAIN Jakarta Jurusan Syari'ah, S-2 lulusan IAIN Jakarta Jurusan Ilmu Agama Islam); 5) Drs. E. Syamsuddin (S-1 lulusan IAIN Jakarta Jur Syari'ah); 6) Drs. Romli Suja'i (S-1 lulusan IAIN Jakarta Jurusan Syari'ah, S-2 lulusan UIKA Bogor Jurusan Ekonomi Syari'ah); 7) Furqon Syarif Hidayatulloh, S.Ag (S-1 lulusan IAIN Bandung Jurusan PAI); 8) Asep Nurhalim Lc, (S-1 lulusan LIPIA); 9) Dra. Neneng Hasanah MA (S-1 lulusan UIKA Bogor Jurusan Syariah, S-2 IAIN Jakarta jurusan Hukum Islam) (MKDU IPB, Arsip 2008).

Data di atas menggambarkan bahwa latar belakang pendidikan dosen PAI di IPB cukup beragam. Lulusan yang paling mendominasi adalah lulusan dari jurusan syariah dan dakwah, sementara dosen yang berlatar belakang pendidikan agama Islam masih sedikit. Oleh karena itu, wajar bahwa secara umum, dosen PAI di IPB masih banyak yang belum menguasai metodologi pengajaran/pembelajaran PAI. Tenaga asisten dosen PAI di IPB, setiap semesternya hampir mencapai 150 orang. Hal ini menunjukan bahwa tingkat antusiasme para asisten terhadap pengembangan PAI di lingkungan IPB cukup tinggi. Asisten dosen, secara umum merupakan mahasiswa IPB yang berasal dari berbagai jurusan, telah kuliah minimal di semester III, memiliki kualifikasi keilmuan di bidang agama Isalm yang cukup baik dan bersemangat dalam mendakwahkan ajaran Islam di kalangan kampus. 
1. Manajemen Pengadaan Tenaga Pendidik

Manajemen pengadaan dosen PAI di IPB adalah suatu proses atau prosedur tertentu di bidang pengadaan tenaga pendidik PAI di lingkungan IPB yang mencakup kegiatan; 1) penentuan kebutuhan, 2) rekrutmen dan seleksi, serta 3) pengangkatan dan penugasan. Meskipun secara umum prosesnya sama (penentuan kebutuhan, rekrutmen, seleksi, pengangkatan dan penugasan) namun secara teknis pelaksanaannya berbeda terutama pada pola seleksi yang disesuaikan dengan kondisi dan situasi yang ada. Perbedaan tersebut terbagi ke dalam dua periode yaitu tahun 1977 sampai dengan 1985 dan tahun 2000 sampai dengan 2006.

a. Penentuan Kebutuhan

Atas dasar jumlah dosen Pendidikan Agama Islam yang ada dan kecenderungan jumlah pendaftar mahasiswa baru pada tahun-tahun sebelumnya, tim pendiri Mata Kuliah Pendidikan Agama Islam IPB, sekitar tahun 1970 membuat proyeksi kebutuhan dosen baru Pendidikan Agama Islam. Tim memutuskan bahwa mereka yang diangkat diutamakan memiliki latar belakang pendidikan keilmuan agama Islam seperti IAIN. Hasil seleksi tersebut kemudian diusulkan kepada pimpinan institut (Hasil wawancara dengan Bapak Aziz Darwis pada Jum'at tanggal 11 april 2008).

Pada tahun 1977-1979, pimpinan IPB merespons pengajuan dari tim pendiri Pendidikan Agama Islam tersebut atas perlunya mengangkat dosen tetap Pendidikan Agama Islam dengan jumlah formasi dua orang (namun dalam perjalanannya satu orang pindah ke Kalimantan). Antara tahun 1980-1985 IPB kemudian mengangkat empat orang lagi, tahun 2000 satu orang, tahun 2005 dua orang dan tahun 2006 sebanyak satu orang. Dengan demikian, dalam kurun waktu selama kurang lebih 31 tahun, IPB hanya mengangkat dosen tetap untuk Mata Kuliah Pendidikan Agama Islam sebanyak sembilan orang. Sedangkan dosen luar biasa kurang lebih 12 orang. Dari uraian tersebut menunjukan bahwa ada kesenjangan antara jumlah mahasiswa dengan kebutuhan tenaga dosen. Perbedaan jumlah kebutuhan ini didasarkan pada beban SKS mata kuliah dan jumlah mahasiswa yang semakin meningkat. Pada tahun 1977-1980-an jumlah mahasiswa IPB sekitar 1000 orang (Arsip UP MKDU IPB, tahun 2008). Pada tahun 2000-2005 jumlah mahasiswa IPB sudah mencapai 2900 orang. Pada tahun 2007 jumlah tersebut bertambah menjadi 3019 orang (Direktorat Pendidikan Tingkat Persiapan Bersama: 2007). Dari segi bobot SKS, pada tahun 1977-2003 berbobot 2 SKS dan sekitar tahun 2004 berubah menjadi 3 SKS. Dengan demikian, proyeksi kebutuhan dosen PAI di IPB untuk periode tahun 2000-2005 lebih banyak dibanding pada tahun-tahun sebelumnya.

Penentuan kebutuhan dosen baru di IPB, secara umum sejalan dengan teori analisis kebutuhan pegawai, yakni dilaksanakan melalui kegiatan penentuan jumlah dan penentuan kualifikasi. Dalam hal penentuan jumlah kebutuhan dosen baru, perhitungannya didasarkan kepada jumlah pegawai yang ada, beban kerja dan kemungkinan ketersediaan formasi. Sementara dari segi kualifikasi, 
penentuannya didasarkan oleh IPK dan nilai tertinggi hasil seleksi (Uwes, 1999: 87).

b. Rekrutmen dan Seleksi

Dalam konteks pengadaan dosen baru Pendidikan Agama Islam, rekrutmen yang dilakukan oleh IPB dimaksudkan sebagai sebuah proses untuk mendapatkan calon dosen yang sesuai dengan kebutuhan mahasiswa IPB secara umum yakni kecuali ahli di bidang agama Islam juga responsif terhadap perkembangan ilmu pengetahuan dan teknologi. Sedangkan yang dimaksud dengan seleksi adalah menyaring calon-calon pelamar yang telah memenuhi persyaratan dan kemungkinan dapat diangkat menjadi dosen Pendidikan Agama Islam di IPB.

Sejak tahun 1977 sampai dengan 2006 rekrutmen calon dosen Pendidikan Agama Islam di IPB tidak selalu persis sama. Pada tahun 1977-1985-an rekrutmen dilakukan dengan cara tertutup. Maksudnya, sistem informasi perekrutannya tidak disebarluaskan ke publik, sehingga untuk pengangkatannya tidak melalui seleksi baik tulis maupun lisan/wawancara, akan tetapi langsung diajukan ke bagian kepegawaian melaui Fakultas MIPA (Wawancara dengan Syamsuddin, kordinator PAI, pada hari Sabtu tanggal 19 April 2008). Alasannya, pada waktu itu Mata Kuliah Pendidikan Agama Islam berada di bawah Fakultas MIPA. Hal ini menunjukkan bahwa pada tahun 1977 hingga 1985, pola rekrutmen dosen baru PAI yang dilakukan oleh IPB, dapat dikatakan didasarkan pada unsur kedekatan antara pihak calon dosen dengan institusi.

Pada tahun 2000, yaitu pada masa Romli Suja'i menjabat sebagai koordinator, rekrutmen mulai dilakukan dengan cara terbuka. Menurut Uwes terbuka artinya, informasi mengenai perekrutan tenaga dosen PAI diumumkan dan disebarluaskan secara terbuka ke publik, baik melalui pelbagai institut pendidikan tinggi maupun melalui iklan surat kabar (1999: 95). Pada waktu itu, IPB memiliki beberapa calon untuk diseleksi. Sistem seleksi yang dilakukan pada periode ini berupa tes lisan yaitu wawancara. Pimpinan menunjuk Ibnul Qayim menjadi orang yang bertugas mewawancara dan menyeleksi para calon.

Pada tahun 2005, kembali pengangkatan/rekrutmen dosen PAI di IPB, dilakukan secara terbuka. Saat itu informasi tentang adanya formasi untuk tenaga dosen Mata Kuliah Pendidikan Agama Islam disebarluaskan kepada publik melalui papan pengumuman lowongan kerja dan lewat iklan di surat kabar/media cetak. Hal yang membedakan dengan rekrutmen periode tahun 2000 adalah pada sistem seleksinya. Pada tahun 2005, seleksi dilakukan melalui dua tahap. Pertama, melalui tes tulis, yang difokuskan pada tes kemampuan akademik dan wawasan kebangsaan. Kedua, tes wawancara, fokusnya menguji metodologi serta pengalaman dalam mengajar. Di samping itu dilakukan juga seleksi administrasi yang meliputi kelengkapan Ijazah, kartu kuning dan Surat Catatan Dari Kepolisian (SKCK)/"surat kelakuan baik".

Sehubungan dengan sistem rekrutmen tersebut, kemungkinan besar polanya didasarkan pada Ketetapan Majelis Wali Amanat Institut Pertanian 
Bogor Nomor 17/MWA-IPB/2003 Tentang Anggaran Rumah Tangga Institut Pertanian Bogor, Bab XII, Pasal 80 ayat 1 dan 2 yang berbunyi: (1) Pegawai Institut yang selanjutnya disebut pegawai terdiri atas Dosen Tetap dan Tenaga Penunjang Tetap yang diangkat oleh Institut. (2) Jumlah dan jenis pegawai ditetapkan melalui analisis kebutuhan yang didasarkan pada optimalisasi pelaksanaan pekerjaan. Pegawai yang akan diangkat pun harus memenuhi beberapa kriteria yang disebutkan dalam Pasal 81 yaitu: (1) Beriman dan bertakwa kepada Tuhan Yang Maha Esa; (2) Bermoral, jujur dan menegakkan kebenaran; (3) Bertanggung jawab terhadap tugas yang diemban; (4) Profesional dalam bidangnya; (5) Mampu melaksanakan tugas sesuai dengan yang diminta oleh Institut; (6) Mampu bekerjasama dan berkomunikasi dengan baik; dan (7) Setia kepada institut.

Sistem penerimaan dan pengangkatan pegawai sebagaimana dijelaskan dalam Ketetapan Majelis Wali Amanat Institut Pertanian Bogor Nomor 17/MWA-IPB/2003 Tentang Anggaran Rumah Tangga Institut Pertanian Bogor, Bab XII, harus mengacu kepada pasal 82 yakni: (1) Penerimaan pegawai dilaksanakan secara terbuka dan diumumkan secara luas; dan (2) Tata cara penerimaan dan pengangkatan pegawai ditetapkan dengan Keputusan Rektor (Institut Pertanian Bogor, 2003). Dengan demikian, sejak ada ketetapan Majelis Wali Amanat IPB Nomor 17 MWA-IPB/2003, sistem pengadaan pegawai termasuk dosen dilakukan dengan cara terbuka dan/atau disebarluaskan. Berarti sistem rekrutmen dan seleksi untuk pengadaan dosen Pendidikan Agama Islam di Perguruan Tinggi Umum IPB sejak tahun 1977 sampai 2006 berbeda dan cenderung tidak pernah sama.

Pada periode awal, sistem/pola rekrutmen yang digunakan lebih didasarkan pada pemupukan/pengkaderan atas orang-orang yang berportensi dalam bidang PAI dan sifatnya tertutup, artinya tidak ada tes baik secara tertulis maupun lisan/wawancara. Pada periode kedua hingga sekarang, rekrutmen dilakukan secara terbuka. Dalam rangka seleksi, digunakan tes lisan berupa wawancara. Pada periode ketiga, rekrutmen juga dilakukan secara terbuka. Proses seleksi pun mengacu pada seleksi calon pegawai negeri sipil pada umumnya yaitu seleksi administrasi dan seleksi pengetahuan. Seleksi administrasi ialah seleksi terhadap sejumlah kelengkapan yang dipersyaratkan dan dimaksudkan sebagai acuan untuk dianggap memenuhi atau belum. (2) Seleksi pengetahuan yang berupa: (a) Pengetahuan umum (Pancasila, sejarah Indonesia, tata Negara Indonesia, Bahasa Indonesia, GHHN, Kebijakan pemerintah; (b) Pengetahuan teknis/substansi yaitu pengetahuan dalam bidang keahlian yang bersangkutan; dan (c) lain-lain yaitu pengetahuan yang dipandang perlu (Daryanto, 2006: 142).

c. Pengangkatan dan Penugasan

Langkah berikutnya, setiap pelamar yang telah lulus dalam ujian seleksi baik seleksi adiministrasi maupun seleksi pengetahuan kemudian diusulkan untuk diangkat menjadi Calon Pegawai Negeri Sipil. Selama dalam masa percobaan, kepadanya diberikan gaji pokok ditambah dengan tunjangan-tunjangan yang 
berlaku. Calon Pegawai Negeri Sipil yang telah menjalani masa percobaan, sekurang-kurangnya satu tahun, dapat diangkat menjadi Pegawai Negeri Sipil dalam pangkat tertentu sesuai dengan ketentuan yang berlaku. Proses ini lazim dilakukan oleh instansi pemerintah pada umumnya (Daryanto, 2006: 143).

Data dan analisis di atas menunjukan bahwa dalam proses pengadaan dosen baru PAI di IPB terutama yang statusnya sebagai PNS/pegawai tetap mulai dilakukan sekitar pada tahun 1977. Pengangkatan berikutnya berturut-turut dilaksanakan pada tahun 1980, 1981, 1985, 2000, 2005 dan 2006. Sedangkan untuk pengangkatan dosen yang berstatus Luar Biasa (LB) dari sejak awal sampai sekarang tidak ada batasan yang pasti. Artinya, sejauh ada orang yang berkenan untuk mengajar PAI dan tidak ada hal-hal yang menimbulkan dampak yang kurang baik bagi citra PAI, diperbolehkan untuk aktif di PAI. Sejak tahun 1977 sampai dengan 2006 jumlah dosen tetap PAI di IPB sebanyak 9 orang. Adapun jumlah mahasiswa yang mendapatkan Mata Kuliah PAI pada saat ini sekitar 2700 orang. Berarti 1 orang dosen mengurusi/mengajar 350 mahasiswa. Dengan melihat perbandingan tersebut yaitu $1: 350$, maka kebutuhan dosen agama Islam di IPB masih kurang. Dilihat dari latar belakang pendidikan, dosen PAI di IPB didominasi oleh lulusan dari IAIN (sekarang UIN) dengan berbagai jurusan seperti Syari'ah, Dakwah dan Pendidikan Agama Islam. Dari ketiga jurusan tersebut yang paling dominan adalah lulusan Jurusan Syari'ah.

Kondisi di atas menunjukan bahwa: (1) dalam proses pengangkatan tenaga pendidik PAI di IPB yang berstatus PNS agak kurang teratur. Artinya rentang waktu pengangkatan di masa awal sangat berdekatan dengan pengangkatan berikutnya. Selisihnya hanya sekitar satu tahun. Sedangkan untuk periode berikutnya yaitu dari tahun 1985 ke tahun 2000 rentangnya sangat jauh sekali, begitu juga dari tahun 2000 ke tahun 2005 selisihnya hampir lima tahun. Akibat dari rentang pengangkatan yang cukup jauh, maka regenerasi, pembibitan dan pembinanan dosen Agama Islam di IPB menjadi agak lambat. Akibatnya, ada kesenjangan antara dosen senior dengan junior. Mereka yang merasa junior agak segan untuk berkomunikasi, bekerjasama dan menyampaikan ide kepada seniornya; (2) rasio antara jumlah dosen tetap dengan jumlah mahasiswa yang mendapatkan Mata Kuliah Agama Islam pada saat ini, masih tidak seimbang. IPB membuat kebijakan dengan mengangkat dosen LB sebanyak 12 orang. Berarti secara keseluruhan ada 21 tenaga pendidik Agama Islam di IPB. Kini, rasio dosen dengan mahasiswa berubah menjadi 1:128. Rasio ini pun masih dipandang kurang seimbang. Persoalan lain muncul sebab intensitas mengajar antara dosen tetap dengan dosen LB pun berbeda. Dosen LB umumnya jarang berada di kampus. Dengan demikian IPB masih perlu mengangkat dosen PAI yang statusnya dosen tetap atau PNS (Pegawai Negeri Sipil).

2. Manajemen Pembagian Jadwal Mengajar

Manajemen pembagian jadwal mengajar PAI di IPB merupakan serangkaian prosedur penetapan jadwal mengajar yang meliputi kegiatan 
pembagian kelas, penentuan jumlah dosen dalam setiap kelas, penentuan jumlah mengajar dalam satu semester dan pembagian materi. Sebagai bagian dari proses penyelenggaraan Pendidikan Agama Islam di Perguruan Tinggi Umum IPB, pembagian jadwal dapat berdampak pada proses pembelajaran di kelas. Pembagian jadwal yang tidak teratur akan berakibat di satu sisi menumpuknya jumlah jam mengajar pada salah satu dosen dan di sisi lain terjadi kekurangan jam mengajar pada dosen yang lain. Ketika hal tersebut terjadi maka ada kesenjangan jumlah jam mengajar di antara dosen PAI di IPB. Ada dosen yang jadwal mengajarnya banyak dan ada dosen yang jadwal mengajarnya sedikit.

Manajemen penjadwalan Pendidikan Agama Islam yang diterapkan oleh IPB lebih banyak menggunakan sistem musyawarah (Hasil wawancara dengan Syamsuddin pada hari Sabtu tanggal 19 April 2008, dan Asep Nurhalim pada hari Jum'at tanggal 1 April 2008). Biasanya dalam pelaksanaan penjadwalan, dosen diberi kebebasan memilih jadwal berdasarkan kesiapannya. Tidak ada unsur paksaan terhadap dosen tertentu untuk mengajar pada waktu/kelas dan jam tertentu.

Pada tahun 1977-an, proses penjadwalan biasanya diawali dengan lokakarya, dengan membahas hal-hal yang dianggap baru untuk dijadikan bahan materi pengajaran, sehingga dalam setiap semester senantiasa terjadi penambahan isi/materi (Wawancara dengan Komariah pada hari Kamis tanggal 10 April 2008). Sejak tahun 1977 hingga 1985-an, jadwal perkuliahan Pendidikan Agama Islam hanya dilaksanakan pada hari Jum'at. Oleh karena itu, dalam satu minggu, perkuliahan agama Islam dilakukan secara serempak dalam satu hari, yakni hari Jum'at. Dosen menjadi sering bertemu dalam satu waktu, sehingga komunikasi antar dosen PAI dapat dilakukan dengan mudah.

Manajemen penjadwalan yang diterapkan saat ini pada prinsipnya sama dengan masa lalu yaitu mengedepankan sistem musyawarah. Langkah-langkah yang ditempuh dalam acara penjadwalan yaitu; 1) Setiap menjelang perkuliahan perdana, semua dosen diundang untuk memilih dan menentukan jadwal mengajar yang telah dirancang oleh Direktorat TPB (Tingkat Persiapan Bersama); 2) Jadwal yang telah dibuat oleh TPB kemudian ditulis di papan tulis atau dibacakan; dan 3) Jadwal tersebut kemudian ditawarkan kepada para dosen untuk dipilih dan ditentukan hari, kelas dan waktunya sesuai dengan kesiapan dosen. (hasil wawancara dengan Syamsudin pada hari Sabtu tanggal 19 April 2008 dan Direktorat PTPB).

\section{Manajemen Pembelajaran PAI di IPB}

Manajemen pembelajaran PAI di lingkungan IPB adalah program, prosedur, proses dan pelaksanaan belajar-mengajar/tatap muka Mata Kuliah PAI yang meliputi kegiatan pemilihan materi/kurikulum, metode, media, teknik dan evaluasi. Ditinjau dari segi pola atau bentuk penyampaian materi, manajemen pembelajaran yang diterapkan pada Mata Kuliah Pendidikan Agama Islam di IPB adalah: 1) kegiatan kuliah di kelas, yang dipandu oleh dua atau tiga dosen secara 
bergiliran, dan 2) kegiatan asistensi. Kegiatan asistensi ini dilakukan sejak tahun 1963 sampai 2003-an. Kegiatan ini sifatnya tidak wajib (nonformal) (hasil wawancara dengan Syamsuddin, hari Sabtu tanggal 19 April 2008), sehingga dalam kegiatannya tidak terlalu ditekankan. Namun sejak tahun 2004-an kegiatan asistensi ini mulai diformalkan (wajib) melalui SK rektor. Di samping kegiatan asistensi ada juga kegiatan Studium General (SG) yang dilakukan satu kali dalam semester, materinya bersifat mengungkap hal-hal baru atau aktual.

Pembelajaran PAI di IPB pada dasarnya adalah proses terjadinya interaksi antara pendidik dengan peserta didik. Interaksi tersebut dilakukan melaui sejumlah langkah dan tahapan tertentu yaitu: Pertama, kegiatan awal atau pembukaan yang meliputi: 1) pembacaan al-Qur'an, yang dibacakan oleh seorang mahasiswa atau secara bersama-sama antara dosen dengan mahasiswa, 2) pada pertemuan perdana sebelum menyampaikan materi yang menjadi kegiatan inti, terlebih dahulu biasanya disampaikan silabi, penyampaian tujuan PAI, kontrak kuliah serta penyampaian sistem penilaian. Kedua, kegiatan inti yaitu penyampaian materi. Ketiga, penutup yang meliputi kegiatan: 1) menyimpulkan materi yang telah disampaikan, 2) pembacaan hamdalah dan do'a kafarah al majlis, dan 3) pemberian tugas.

Dalam proses penyampaian materi, dosen lebih banyak menyampaikan materi secara global (uraian singkat berupa intisari dari setiap pokok bahasan) melalui media/alat pendidikan yang tersedia. Media yang digunakan dalam pengajaran PAI di IPB dari tahun ke tahun terus mengalami perkembangan. Sesuai dengan kondisi yang ada pada saat awal berdirinya IPB, media yang tersedia adalah al-Qur'an, kapur, papan tulis dan "transfaransi". Hal ini terjadi dari sejak tahun 1963 hingga 1980-an (Wawancara dengan Komariah, hari Kamis tanggal 10 April 2008) dan cara menggunakannya langsung oleh dosen yang bersangkutan.

Pada tahun 1983-an, media pembelajaran Pendidikan Agama Islam ditambah dengan OHP. Dengan demikian sejak tahun 1983-an, media yang digunakan dalam pembelajaran PAI umumnya menggunakan papan tulis dan alat tulis, ditambah dengan OHP dan transfaransi, buku panduan serta al-Qur'an. Cara penggunaannya langsung dikerjakan oleh dosen yang bersangkutan (Wawancara dengan Syamsudin, hari sabtu tanggal 19 April 2008). Pemilihan dan penggunaan media tersebut berlangsung hingga akhir tahun 2005-an.

Mulai tahun 2006, media yang dipakai dalam penyelenggaraan Pendidikan Agama Islam di IPB meliputi: buku panduan PAI, panduan Asistensi, al-Qur'an, spidol, papan tulis, transfaransi, wireless, speaker/pengeras suara, LCD dan Laptop/note book. Cara penggunaanya, khusus untuk LCD dan laptop dioperasikan oleh seorang operator, sedangkan transfaransi digunakan langsung oleh dosen yang bersangkutan (Wawancara dengan Musthofa, hari Jum'at tanggal 11 April 2008).

Dilihat dari urutan pokok bahasannya, materi PAI yang disampaikan dalam program kuliah di kelas memiliki perbedaan terutama antara tahun 1980- 
an hingga sekarang. Pada tahun 1984 ke bawah, materi pokok PAI di IPB meliputi; Bab I (Al-Qur'an dan Ilmu Pengetahuan), Bab II (Manusia dan Agama), Bab III (Akidah Islamiyah), Bab IV (Syari'ah Islamiyah), Bab V (Akhlak) (Kusumamuhardja dkk., 1985). Saat ini, pokok bahasan PAI di IPB meliputi; Bab I (Pandangan Islam terhadap Pengembangan Ilmu Pengetahuan), Bab II (Manusia dan Agama), Bab III (Akidah Islamiyah), Bab IV (Syariah Islamiyah dan Mu'amalah) Bab V (Akhlak Islamiyah), Bab IV (Dakwah) (Tim Pendidik Agama Islam, 2007). Dengan demikian, secara umum, materi PAI di IPB dari dulu sampai sekarang prinsipnya sama, namun pada saat ini sudah ditambah dengan pokok bahasan Mu'amalah dan Dakwah.

Dalam kegiatan asistensi, mahasiswa dikelompokan menjadi beberapa kelompok kecil. Jumlah mahasiswa per kelompok sekitar 10-15 orang yang dibimbing atau dipandu oleh seorang asisten. Materi yang disampikan dalam kegiatan asistensi pada prinsipnya adalah sama dengan materi yang disampikan di kelas. Namun yang ditekankan dalam kegiatan asistensi ini adalah mengembangkan materi yang disampaikan di kelas agar menjadi lebih aplikatif. Pada tahun 1990-an pelaksanaan kegiatan asistensi meliputi: 1) diskusi, 2) baca Al-Qur'an, 3) praktik ibadah (Hafifuddin, tt). Kini, program asistensi yang dilakukan meliputi; 1) tilawah Al-Qur'an, 2) presentasi materi oleh praktikan, 3) hafalan al-Qur'an, 4) qui dan penugasan (Furqon, 2008), dan dalam kondisi tertentu diadakan kegiatan riblah dan Kontemplasi.

\section{SIMPULAN}

Manajemen Pendidikan Agama Islam di Institut Pertanian Bogor melingkupi sejumlah kegiatan yaitu; 1) Program pengadaan dosen baru PAI. Program tersebut dilaksanakan melalui; (a) penentuan kebutuhan, (b) rekrutmen dan seleksi, dan (c) pengangkatan dan penugasan. Pelaksanaan seleksi dilakukan dalam beberapa cara yaitu; a) seleksi tanpa tes, b) seleksi dengan tes wawancara, dan c) seleksi dengan tes tertulis dan wawancara. Untuk pengadaan dosen honorer/Luar Biasa dilakukan secara fleksibel/kapan saja sepanjang ada orang/intelektual Muslim yang berniat untuk mengembangkan ilmu agamanya di IPB. Kriteria umumnya, di samping memiliki wawasan keagamaan Islam yang luas juga memiliki akhlak dan fikrah yang baik); 2) Manajemen pembagian jadwal mengajar Mata Kuliah PAI. Kegiatan ini dijalankan utamanya melalui sistem musyawarah. Sistem tersebut menempuh langkah-langkah; (a) Kordinator Tim PAI mengundang semua dosen PAI, (b) Setiap dosen diminta untuk memilih hari, jam dan kelas sesuai dengan kesiapannya meskipun demikian tetap harus mengacu pada jadwal dari pusat/rektorat, (c) Dosen memilih dosen lain sebagai pendamping; 3) Manajemen pembelajaran PAI. Dalam proses pembelajaran PAI di IPB dikembangkan program; kuliah, asistensi, dan studium general. Dalam proses pembelajaran di kelas, umumnya kegiatan yang dilakukan adalah (a) pembukaan yang disisi dengan membaca/tilawah al-Qur'an bersama, (b) kegiatan inti berupa penyampaian materi secara global, (c) penutup yang di isi dengan 
penyimpulan dan pembacaan do'a kafarah al majlis. Dalam proses pengajarannya, secara umum dosen banyak menggunakan metode ceramah, tanya jawab dan diskusi. Kemudian dilengkapi dengan media yang pada saat ini telah menggunakan antara lain; slide, in focus, laptop dan bahan ajar lain yakni berupa buku/diktat. Program asistensi dilakukan dalam rangka mengaplikasikan pelbagai materi kuliah, ditambah dengan hafalan al-Qur'an, tugas dan Quiz; 4) Program tindak lanjut. Program ini berisi pembinaaan terhadap mahasiswa setelah selesai pembelajaran kuliah PAI selesai. Sifat dari kegiatan/program ini tidak wajib.

\section{DAFTAR PUSTAKA}

Al-Qur'an dan Terjemahan, Komplek percetakan Al-Qur'an Karim kepunyaan Raja Fahd, Madinah.

Daradjat, Zakiah dkk. 1992. Ilmu Pendidikan Islam, Jakarta: Graffika Offset.

Daryanto, 2006. Administrasi Pendidikan, Jakarta: Rineka Cipta.

Departemen Pendidikan Nasional Biro Kepegawaian. 2005. Pembinaan Karier Dosen.

Depdiknas, Direktorat Pembinaan Pendidikan Tenaga Kependidikan dan

Ketenagaan Perguruan Tinggi; Bagian Proyek Peningkatan Tenaga

Akademik. 2004. Buku Petunjuk Pelatihan Dosen Matakuliab Pengembangan

Kepribadian PAI, Padang.

Digital Qur'an versi 3.2.

Direktorat Pendidikan Tingkat Persiapan Bersama, 2007. TPB Dalam Angka.

Direktorat TPB IPB. Tt. Arsif tentang Jumlah mahasiswa TPB-IPB tahun ajaran 2006/2007 dan 2007/2008.

Echols, John M. dan Hassan Shadily. 1996. Kamus Inggris Indonesia. Jakarta: PT Gramedia.

Furqon, Arief. 2004. Kebijakan Ditjen Bagais Tentang PAI di PTU, Materi pelatihan

Dosen Mata Kuliah Pengembangan Kepribadian Pendidikan Agama Islam, Padang, 19 Juli.

Furqon, Syarief, Hidayatulloh, 2008. Panduan Asistensi Pensdidikean Agama Islam TPB IPB, Bogor: Nizar Press.

Hasibuan, Malayu, SP. 2006. Manajemen; Dasar, Pengertian dan Masalah, Jakarta: Bumi Aksara.

Ilyas, Asnelly. 1995. Mendambakan Anak Shaleh. Bandung: Al-Bayan.

Institut Pertanian Bogor, 2003. Ketetapan Majelis Wali Amanat Institut Pertanian Bogor Nomor 17/MWA-IPB/2003 Tentang Anggaran Ruman Tangga IPB.

Jalaludin. 1997. Psikologi Agama, Jakarta: Raja Grafindo Persada.

MKDU IPB. 2008. Arsip, tentang nama-nama dosen tetap P AI tabun 2008.

MKDU IPB. 2008. Arsip, Nama-nama dan tabun pengangkatan dosen PAI di IPB.

Mujib, Abdul. 1999. Fitrah dan Kepribadian Islam, Jakarta: Darul Falah.

Munawwir, A.W. 1984. Kamus AlMunawwir Arab-Indonesia, Yogyakarta: PP Al Munawwir. 
Nasir, Shalihun. 2002. Peranan Pendidikan Agama terhadap Pemecahan Problema Remaja, Jakarta: Kalam Mulia.

Ramayulis, 2005. Metodologi Pendidikan Agama Islam. Jakarta: Kalam Mulia.

Sagala, Syaeful. 2007. Manajemen Strategik Dalam Peningkatan Mutu Pendidikan, Bandung: Alfabeta.

Sanjaya, Wina. 2008. Strategi Pembelajaran, Jakarta: Kencana.

Siagan, Sondang P. 2005. Fungsi-Fungsi Manajerial, Jakarta: Bumi Aksara.

Siswanto. 2005. Panduan Praktis Organisasi Remaja Mesjid,Jakarta Timur: Pustaka Kautsar.

Syafaruddin, 2005. Manajemen Lembaga Pendidikan Islam, Jakarta: Ciputat Press.

Syahidin, 2004. Konsep Pendidikan Agama Islam Pada Perguruan Tinggi Umum, Makalah disampaikan Pada Pelatihan Nasional Dosen Mata Kuliah Pengembangan Kepribadian PAI, Padang.

Syahidin, 2006. Posisi Pendidikan Agama Islam Pada Perguruan Tinggi Umum Di Indonesia, makalah disajikan pada acara pertemuan dan konsultasi nasional pengembangan

Tim Pendidik Agama Islam. 2007. Buku Panduan Penddikan Agama Islam TPB IPB. Uwes, Sanusi. 1999. Manajemen Pengembangan Mutu Dosen,,Jakarta: Logos Wacana. 